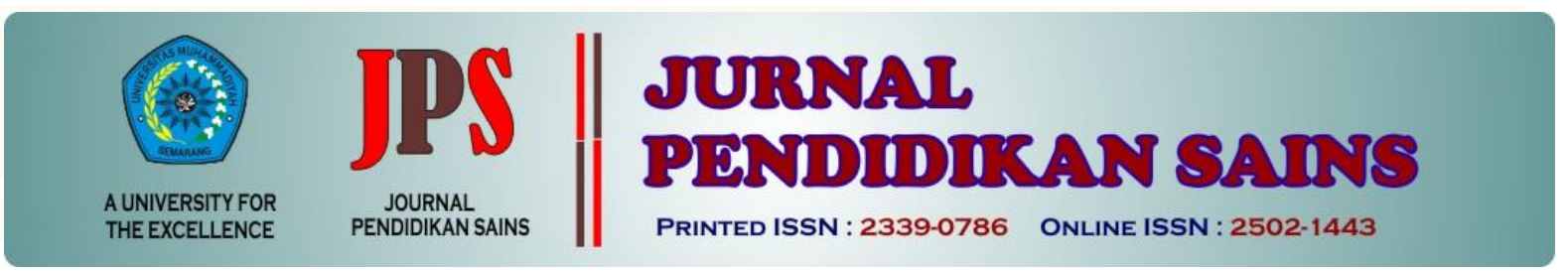

\title{
PENGEMBANGAN INSTRUMEN SIKAP SISWA SEKOLAH MENENGAH PERTAMA TERHADAP MATA PELAJARAN IPA
}

Oleh:

Astalini $^{1}$, Dwi Agus Kurniawan ${ }^{2}$

${ }^{12}$ Program Pendidikan Fisika, Universitas Jambi

\begin{tabular}{|c|c|c|}
\hline Article hist & & Abstract \\
\hline Submission & :2018-09-11 & untuk pengembangan instrumen \\
\hline Revised & : 2018-11-05 & penilaian sikap siswa terhadap mata pelajaran IPA. Instrumen yang \\
\hline Accepted & : 2018-11-29 & $\begin{array}{l}\text { dikembangkan berupa angket yang terbagi menjadi pernyataan positif } \\
\text { dan pernyataan negatif. Metode penelitian yang digunakan adalah }\end{array}$ \\
\hline Keyword: & & Research and Development $(R \& D)$ atau umumnya dikenal dengan \\
\hline $\begin{array}{l}\text { Kata kunci: } \\
\text { sikap siswa }\end{array}$ & $\begin{array}{l}\text { istrumen, } \\
\text { PA }\end{array}$ & $\begin{array}{l}\text { penelitian pengembangan. Responden penelitian adalah siswa SMPN } \\
\text { Se-Kabupaten Muaro Jambi dengan menggunakan teknik purpossive } \\
\text { samplin, dan total sampel penelitian sebanyak } 550 \text { siswa. Hasil } \\
\text { penelitian menunjukkan instrumen angket yang valid sebanyak } 56 \\
\text { butir dari total } 70 \text { butir pernyataan, dengan nilai reliabilitas (cronbach } \\
\text { alpha) sebesar } 0,842 \text {. }\end{array}$ \\
\hline
\end{tabular}

\section{Pendahuluan}

Pendidik dan pemegang kebijakan harus peduli tentang kualitas pendidikan sains dan bagaimana hal ini berkaitan dengan minat dan pemahaman di kalangan anak muda (Blalock, et al 2013: 961).) pendidikan sains adalah salah satu aspek pendidikan yang menggunakan sains untuk mencapai tujuan pendidikan, umumnya tujuan pendidikan nasional dan tujuan pendidikan sains khusunya, yaitu dengan meningkatkan pengetahuan terhadap dunia alamiah (Puti dan Jumadi , 2015 :2). Selama dekade terakhir, para peneliti dalam pendidikan sains telah mengidentifikasi berbagai sikap dan keyakinan siswa yang membentuk dan dibentuk dari pengalaman kelas siswa (Adams, et al, 2006 : 1).

Ilmu pengetahuan alam lebih dekat kepada pembelajaran sains dan berfikir saintis terhadap mata pelajaran IPA. Mata pelajaran IPA merupakan pembelajaran yang ruang lingkup cakupannya lebih kepada alam sekitar dan lingkungannya. IPA merupakan mata pelajaran wajib yang dipelajari di Sekolah Menengah Pertama. IPA menghubungkan cara mencari tahu tentang pengetahuan alam secara sistematis, sehingga pembelajaran IPA merupakan proses pengalaman dan menghasilkan penguasaan pengetahuan berupa pemahaman konsep-konsep. Dalam pembelajaran Ilmu Pengetahuan Alam diharapkan siswa memiliki sikap positif untuk menunjang proses pembelajaran yang baik. Penerimaan atau sikap positif dan penolakan atau sikap negatif dapat dinyatakan dengan sikap persetujuan atau tidak persetujuan terhadap pernyataan sesuatu objek (Darmawangsa, 2017 : $3)$.

Faktor pengaruh siswa memiliki ketertarikan ataupun tidak antara sikap terhadap mata pelajaran IPA dapat diketahui dari kecenderungnan siswa yang menerima ataupun menolak ketika diminta untuk mengerjakan soal yang diberikan. Siswa cenderung aktif jika siswa mempunyai ketertarikan terhadap pelajaran IPA.

*Corresponding Author:

$\begin{array}{ll}\text { Nama } & \text { : Astalini } \\ \text { Lembaga } & \text { : FKIP Universitas Jambi } \\ \text { Email } & \text { : astalinizakir@unja.ac.id }\end{array}$


Sebaliknya siswa pasif cenderung tidak tertarik terhadap pelajaran IPA. Faktor lain yang mempengaruhi sikap siswa terhadap IPA adalah kurangnya fasilitas untuk melakukan percobaan dalam pembelajaran IPA sehingga siswa mengalami kesulitan dalam mengembangkan rasa ingin tahunya. Sikap negatif terhadap sains menjadikan alasan bagi siswa untuk tidak mengikuti pelajaran dalam bidang sains. Selain itu kebanyakan siswa mengangggap bahwa pelajaran sains hanya dipelopori oleh siswa yang pandai atau siswa yang memiliki peringkat yang baik. Keadaan ini menyebabkan sikap yang negatif bagi siswa yang lemah (Kamisah Osman et al, 2007). Berdasarkan penjelasan tersebut jelas bahwa sikap terhadap IPA di Sekolah Menengah Pertama sangatlah penting. Berdasarkan pernyataan tersebut diketahui bahwa pada siswa Sekolah Menengah Pertama belum ada instrumen terkait penilaian sikap siswa terhadap IPA. Padahal dalam menilai sikap siswa terhadap IPA perlu adanya sebuah instrumen.

Instrumen atau alat ukur dalam penelitian yang bisa digunakan dalam pengukuran sikap siswa terhadap IPA adalah instrumen berupa angket. Maka peneliti dalam bidang pendidikan, umumnya instrumen penelitian yang digunakan sering disusun sendiri termasuk menguji validitas dan reliabilitasnya (Sugiyono, 2016). Sikap terhadap IPA/sains dapat diketahui melalui tes atau uji yang dilakukan kepada siswa, dan dikenal sebagai tes sikap. Tes sikap ini telah banyak dibuat oleh ahli, seperti Test of science related attitude (TOSRA) yang dibuat Fraser (1982). TOSRA digunakan dalam pengukuran sikap yang terfokus pada sains, yaitu sikap ilmiah dan sikap terhadap sains. adapun sikap terhadap sains terdapat tujuh dimensi sikap didalam TOSRA. Dimensi sikap tersebut yaitu, social implication of science, normality of scientists, attitude to scientific inquiry, adoption of scientific attitudes, enjoyment of science lessons, leisure interest in science, and career interest in science (Fraser,1982).

Faktanya negara maju telah memiliki istrumen tes sikap terhadap mata pelajaran IPA, contoh Amerika Serikat memiliki beberapa instrument untuk mengukur sikap terhadap sains, misalnya; Colorado Learning Attitude about Science Survey (CLASS), Views About Sciences Survey (VASS) dan the Epistemological Beliefs Assessment for Physical Science (EBAPS). Taiwan RRC Juga memiliki instrumen terhadap sains yaitu: Views on Science and Education Questionnaire (VNOS). Disamping itu Nigeria juga memiliki instrumen seperti yang dua negara tadi miliki yaitu dikenal dengan nama (SSAQ) atau Science Students' Attitude Questionnaire.

\section{Metode Penelitian}

Metode penelitian yang digunakan adalah metode penelitian dan pengembangan atau Research and Development (R\&D). Metode Research and Development (R\&D) menurut Sugiyono (2016) merupakan metode penelitian yang digunakan untuk tujuan menghasilkan produk tertentu, serta untuk menguji keefektifan produk tersebut. Penelitian ini, peneliti mengembangkan instrument angket sikap siswa terhadap IPA. Indikator dikembangkan berdasarkan dimensi sikap pada Test of science related attitude (TOSRA) yang dimiliki oleh Fraser (1982). Fraser membagi TOSRA menjadi 7 dimensi sikap yang dialihbahasakan dari bahasa inggris ke bahasa Indonesia. 7 dimensi sikap itu yakni, Implikasi sosial dari IPA, normalitas ilmuwan, sikap terhadap penyelidikan dalam IPA, adopsi dari sikap ilmiah, kesenangan dalam belajar IPA, ketertarikan memperbanyak waktu belajar IPA, dan ketertarikan berkarir dibidang IPA. Dari 7 indikator memiliki 10 butir pernyataan dari tiap masing-masing indikator. Sehingga memiliki jumlah total 70 butir pernyataan. Berikut kisi-kisi pengukuran angket sikap tehadap IPA.

Tabel 1. Angket pengukuran sikap siswa terhadap mata pelajaran IPA

\begin{tabular}{ll}
\hline Dimensi Sikap & Nomor Butir \\
\hline Implikasi Sosial dari IPA & $1,8,15,22,29,36,43,50,57,64$ \\
\hline Normalitas Guru & $2,9,16,23,30,37,44,51,58,65$ \\
\hline Sikap terhadap penyelidikan dalam IPA & $3,10,17,24,31,38,45,52,59,66$ \\
\hline Adaptasi dari sikap ilmiah & $4,11,18,25,32,39,46,53,60,67$ \\
\hline Kesenangan dalam belajar IPA & $5,12,19,26,33,40,47,54,61,68$ \\
\hline Ketertarikan memperbanyak waktu belajar IPA & $6,13,20,27,34,41,48,55,62,69$ \\
\hline Ketertarikan berkarir dibidang IPA & $7,14,21,28,35,42,49,56,63,70$ \\
\hline
\end{tabular}

Pengembangan instrument pengukuran kuantitatif. Data kualitatif diperoleh dari lembar validasi berupa saran dan pernyataan dari dosen sikap menggunakan jenis data kualitatif dan data ahli mengenai instrumen pengukuran sikap 
berupa angket. Adapun validasi instrumen ini dilakukan oleh 2 dosen ahli sebagai validator yaitu bapak Drs. Maison., M.Si, Ph.D dan bapak Haerul Pathoni., S.Pd, M.PFis. Sedangkan data kuantitatif diperoleh dari lembar validasi yang telah diisi dosen ahli dan angket yang disebarkan kepada siswa bertujuan mengetahui validitas dan reliabilitas angket. Uji validitas menurut Hairida (2017) bertujuan untuk mengetahui tingkat ketepatan suatu tes terhadap apa yang diukur oleh tes tersebut. Sedangkan reliabilitas menurut Dhamayanti et al (2018) bertujuan untuk mengetahui sejauh mana tingkat kepercayaan hasil dalam pengukuran atau sejauh mana pertanyaan maupun pernyataan dapat dipahami sehingga tidak akan menyebabkan perbedaan interpretasi subjek dalam memahami pertanyaan. Uji validitas dan reliabilitas angket menggunakan aplikasi SPSS v.24.

Sampel dalam penelitian ini adalah siswa SMPN Se-Kabupaten Muaro Jambi. Adapun teknik pengambilan sampel yang menggunakan purposive sampling. purposive sampling merupakan teknik penentuan/pengambilan sampel berdasarkan pertimbangan tertentu. Jumlah sampel yang dijadikan sebagai subjek ujicoba angket sebanyak 550 siswa.

\section{Hasil Penelitian dan Pembahasan \\ 1. Deskripsi permasalahan}

Hasil dari penelitian pengembangan ini berupa instrumen angket yang berguna untuk mnegukur sikap siswa terhadap IPA. Pengembangan angket ini menggunakan model pengembangan yang dikemukakan oleg Sugiyono dilakukan melalui delapan tahapan, yaitu identifikasi masalah, desain produk, validitas desain, revisi desain, uji coba produk, dan revisi produk.

Dalam kegiatan studi pendahuluan, peneliti mengkaji literatur tentang instrumen penelitian sikap siswa terhadap IPA. Ternyata instrumen penilian sikap siswa terhadap pembelajaran IPA belum ada instrumen yang dirancang khusus pada pelajaran IPA, baik dari buku-buku ataupun jurnal. Seperti halnya sekolah di Muaro Jambi khususnya SMP, belum ada instrumen khusus untuk menilai sikap siswa terhadap IPA. Melihat keadaan ini, dirasa perlu untuk mengembangkan instrumen tersebut.

\section{Validitas \\ a. Validasi Ahli}

Validitas adalah menunjukkan sejauh mana suatu alat ukur mampu dalam mengukur apa yang akan diukur (Siregar, 2015). Pada tahap ini uji validasi yang dilakukan yaitu validasi oleh dosen ahli. Validasi dosen ahli bertujuan untuk mengetahui kelayakan setiap butir dari pernyataan serta untuk memenuhi validitas isi dan validitas tampang. Kegiatan validasi ahli menurut Sulistyani (2015:201) bertujuan mendapatkan data mengenai kevalidan perangkat yang dihasilkan.

Validasi dosen ahli ini dilakukan beberapa kali sehingga diperoleh instrumen angket yang valid. Validasi tahap 1 yaitu Validator fokus kepada tata bahasa dari tiap-tiap butir dalam 2 indikator angket atau 20 item pernyataan. Validasi tahap 2 yaitu Validator melanjutkan pemeriksaan pada indikator selanjutnya. Validator juga menyarankan untuk mengubah kata fisika menjadi IPA karena instrumen angket ini tujuannya untuk pengukuran sikap siswa pada mata pelajaran IPA. Validasi tahap 3 yaitu Validator menyarankan untuk memperhatikan penggunaan huruf kapital sesuai dengan aturan tulis menulis. Selanjutnya Validator menyarankan untuk menghilangkan item nomor 62. Item tersebut dirasa tidak tepat dengan kondisi siswa di Indonesia khususnya Jambi.

Item nomor 62 berisikan tentang kesenangan siswa mengunjungi museum IPA diakhir pekan. Item dengan nomor 62 dihapus atas pertimbangan pernyataan yang terkandung didalamnya tidak sesuai dengan daerah dimana instrumen akan digunakan. Hal ini senada dengan uraian Kasnodihardjo (1993), bahwa masalah penting yang sering timbul dari penggunaan kuesioner dalam suatu survei adalah adanya variasi dari responden terutama menyangkut (a) tingkat pendidikan, (b) prejudice, (c) perbedaan daerah dimana responden bertempat tinggal, (d) latar belakang pekerjaan. Peneliti setuju dengan uraian diatas karena instrumen ini nantinya akan digunakan di Indonesia khususnya Jambi, sedangkan faktanya di Indonesia masih belum terdapat museum khusus IPA.

\section{b. Validasi menggunakan SPSS}

Validitas instrumen merupakan ketetapan dalam mengukur apa yang seharusnya di ukur melalui item-item pada instrumen (Astuti, 2015:241). Validitas ini dulakukan untuk mengetahui kelayakan dari setiap butir soal. Pengujian validitas dalam menganalisis hasil uji coba dilakukan menggunakan aplikasi SPSS 24. Berdasarkan hasi uji coba menggunakan pemograman SPSS 24 adapun item pernyataan angket sikap siswa terhadap pelajaran IPA yang 
tergolong valid dan tidak valid terdapat pada tabel dibawah ini:

Tabel 2. Butir Pernyaaan Angket Sikap Siswa Terhadap Mata Pelajaran IPA Yang Valid dan Tidak Valid

\begin{tabular}{|c|c|c|c|c|c|c|}
\hline \multirow[t]{2}{*}{ Indikator } & \multicolumn{2}{|c|}{$\begin{array}{c}\text { Butir Pernyataan } \\
\text { Valid }\end{array}$} & \multirow{2}{*}{$\begin{array}{c}\text { Juml } \\
\text { ah }\end{array}$} & \multicolumn{2}{|c|}{$\begin{array}{c}\text { Butir Pernyataan } \\
\text { Tidak Valid }\end{array}$} & \multirow[t]{2}{*}{ Jumlah } \\
\hline & $(+)$ & $(-)$ & & $(+)$ & $(-)$ & \\
\hline $\begin{array}{l}\text { Implikasi sosial } \\
\text { dari IPA }\end{array}$ & 15,29 & $1,8,22,64$ & 6 & 57 & 0 & 1 \\
\hline $\begin{array}{l}\text { Normalitas } \\
\text { ilmuan IPA }\end{array}$ & 9,65 & 16,23 & 4 & 30 & 2,58 & 3 \\
\hline $\begin{array}{l}\text { Sikap terhadap } \\
\text { penyelidikan } \\
\text { dalam IPA }\end{array}$ & $3,36,66$ & $\begin{array}{c}10,24,41 \\
50\end{array}$ & 7 & 17,46 & 31,59 & 4 \\
\hline $\begin{array}{l}\text { Adobsi dari } \\
\text { sikap ilmiah }\end{array}$ & $\begin{array}{c}4,11,25 \\
37\end{array}$ & $18,32,42$ & 7 & 60 & 69,67 & 3 \\
\hline $\begin{array}{l}\text { Kesenangan } \\
\text { dalam belajara } \\
\text { IPA }\end{array}$ & $\begin{array}{c}5,19,33 \\
43,51\end{array}$ & $\begin{array}{c}12,26,38 \\
47,53,68\end{array}$ & 11 & 0 & 0 & 0 \\
\hline $\begin{array}{l}\text { Ketertarikan } \\
\text { memperbanyak } \\
\text { waktu belajara } \\
\text { IPA }\end{array}$ & $\begin{array}{c}6,20,34 \\
44\end{array}$ & $\begin{array}{c}13,27,39 \\
48,55\end{array}$ & 9 & 0 & 62,69 & 2 \\
\hline $\begin{array}{l}\text { Ketertarikan } \\
\text { berkariri } \\
\text { dibidang IPA }\end{array}$ & $\begin{array}{c}14,28,4 \\
0,49,54 \\
56\end{array}$ & $\begin{array}{c}7,21,35,4 \\
5,52,64\end{array}$ & 12 & 70 & 0 & 1 \\
\hline Jumlah & 26 & 30 & 56 & 6 & 8 & 14 \\
\hline
\end{tabular}

Berdasarkan tabel di atas, disimpulkan Pernyataan yang tidak valid adalah bahwa pada isntrumen angket sikap siswa pernyataan yang kurang relevan dengan terhadap IPA, terdiri dari 70 butir soal terdiri kondisi siswa di SMP Muaro Jambi, dari 56 butir pernyataan valid, yang terbagi misalnya ketertarikan meluangkan waktu di menjadi 26 pernyataan positif dan 30 museum IPA, sedangkan di Muaro Jambi pernyataan negatif. Sedangkan angket tidak tidak ada museum. Berikut adalah hasil valid berjumlah 14 butir pernyataan. analisis data menggunakan SPSS :

Tabel 3 Hasil Validitas Dan Reliabilitas

\begin{tabular}{cccccc}
\hline item & $\begin{array}{c}\text { Scale } \\
\text { Mean if } \\
\text { Item } \\
\text { Deleted }\end{array}$ & $\begin{array}{c}\text { Scale } \\
\text { Variance } \\
\text { if Item } \\
\text { Deleted }\end{array}$ & $\begin{array}{c}\text { Corrected } \\
\text { Item-Total } \\
\text { Correlation }\end{array}$ & $\begin{array}{c}\text { Cronbach's } \\
\text { Alpha if } \\
\text { Item } \\
\text { Deleted }\end{array}$ & $\begin{array}{c}\text { Keterangan } \\
\text { Validitas } \\
5 \%(0,088)\end{array}$ \\
\hline S1 & 502,6280 & 1777,400 & 0,230 & 0,715 & Valid \\
\hline S2 & 503,8480 & 1789,259 & 0,056 & 0,717 & Tidak \\
\hline S3 & 503,2320 & 1785,966 & 0,095 & 0,717 & Valid \\
\hline S4 & 503,7520 & 1782,435 & 0,111 & 0,716 & Valid \\
\hline S5 & 502,9060 & 1756,879 & 0,465 & 0,712 & Valid \\
\hline S6 & 503,3980 & 1756,541 & 0,443 & 0,712 & Valid \\
\hline S7 & 503,3940 & 1762,315 & 0,360 & 0,713 & Valid \\
\hline
\end{tabular}




\begin{tabular}{|c|c|c|c|c|c|}
\hline S8 & 502,9400 & 1757,836 & 0,435 & 0,712 & Valid \\
\hline s9 & 503,1540 & 1772,832 & 0,254 & 0,715 & Valid \\
\hline S10 & 503,7500 & 1781,250 & 0,129 & 0,716 & Valid \\
\hline S11 & 502,8640 & 1774,835 & 0,232 & 0,715 & Valid \\
\hline $\mathrm{S} 12$ & 503,0820 & 1758,300 & 0,437 & 0,712 & Valid \\
\hline $\mathrm{S} 13$ & 503,1880 & 1761,263 & 0,384 & 0,713 & Valid \\
\hline $\mathrm{S} 14$ & 503,2580 & 1753,731 & 0,451 & 0,711 & Valid \\
\hline $\mathrm{S} 15$ & 502,9940 & 1766,383 & 0,347 & 0,713 & Valid \\
\hline S16 & 503,3640 & 1783,523 & 0,118 & 0,716 & Valid \\
\hline $\mathrm{S} 17$ & 503,8300 & 1794,161 & $-0,005$ & 0,718 & Tidak \\
\hline $\mathrm{S} 18$ & 502,9860 & 1770,771 & 0,267 & 0,714 & Valid \\
\hline S19 & 504,0920 & 1766,064 & 0,300 & 0,714 & Valid \\
\hline $\mathrm{S} 20$ & 503,2400 & 1761,477 & 0,367 & 0,713 & Valid \\
\hline $\mathrm{S} 21$ & 503,3400 & 1762,862 & 0,385 & 0,713 & Valid \\
\hline S22 & 503,1700 & 1760,951 & 0,370 & 0,713 & Valid \\
\hline $\mathrm{S} 23$ & 503,3080 & 1772,803 & 0,238 & 0,715 & Valid \\
\hline S24 & 503,4320 & 1779,252 & 0,139 & 0,716 & Valid \\
\hline S25 & 503,6280 & 1780,803 & 0,122 & 0,716 & Valid \\
\hline S26 & 503,1580 & 1749,741 & 0,475 & 0,711 & Valid \\
\hline S27 & 503,3900 & 1758,836 & 0,382 & 0,712 & Valid \\
\hline S28 & 503,7580 & 1765,871 & 0,305 & 0,713 & Valid \\
\hline S29 & 503,0500 & 1757,591 & 0,401 & 0,712 & Valid \\
\hline $\mathrm{S} 30$ & 503,5840 & 1794,508 & $-0,007$ & 0,718 & Tidak \\
\hline S31 & 503,9040 & 1785,806 & 0,072 & 0,717 & Tidak \\
\hline S32 & 503,1480 & 1761,774 & 0,368 & 0,713 & Valid \\
\hline S33 & 503,2540 & 1747,557 & 0,520 & 0,710 & Valid \\
\hline S34 & 503,6200 & 1759,783 & 0,403 & 0,712 & Valid \\
\hline S35 & 503,0780 & 1759,475 & 0,402 & 0,712 & Valid \\
\hline S36 & 503,5920 & 1779,869 & 0,141 & 0,716 & Valid \\
\hline S37 & 503,4220 & 1770,781 & 0,279 & 0,714 & valid \\
\hline S38 & 502,8380 & 1751,984 & 0,488 & 0,711 & valid \\
\hline S39 & 503,1080 & 1757,680 & 0,445 & 0,712 & valid \\
\hline $\mathrm{S} 40$ & 503,4540 & 1759,471 & 0,395 & 0,712 & valid \\
\hline S41 & 503,3840 & 1762,341 & 0,315 & 0,713 & valid \\
\hline S42 & 503,2920 & 1768,392 & 0,272 & 0,714 & valid \\
\hline $\mathrm{S} 43$ & 503,2660 & 1743,803 & 0,535 & 0,710 & valid \\
\hline S44 & 503,7140 & 1753,142 & 0,419 & 0,711 & valid \\
\hline $\mathrm{S} 45$ & 503,1860 & 1757,971 & 0,415 & 0,712 & valid \\
\hline S46 & 503,8960 & 1791,568 & 0,025 & 0,718 & tidak \\
\hline S47 & 503,2080 & 1754,947 & 0,435 & 0,712 & valid \\
\hline S48 & 503,3780 & 1761,358 & 0,365 & 0,713 & valid \\
\hline S49 & 503,3240 & 1761,586 & 0,365 & 0,713 & valid \\
\hline S50 & 503,8940 & 1777,566 & 0,173 & 0,715 & valid \\
\hline S51 & 503,4840 & 1757,352 & 0,429 & 0,712 & valid \\
\hline
\end{tabular}




\begin{tabular}{clllll}
\hline S52 & 503,3660 & 1758,734 & 0,394 & 0,712 & valid \\
\hline S53 & 503,2360 & 1758,610 & 0,368 & 0,712 & valid \\
\hline S54 & 503,3320 & 1751,761 & 0,422 & 0,711 & valid \\
\hline S55 & 503,8300 & 1780,646 & 0,137 & 0,716 & valid \\
\hline S56 & 503,2540 & 1769,609 & 0,262 & 0,714 & valid \\
\hline S57 & 503,0860 & 1796,953 & $-0,036$ & 0,719 & tidak \\
\hline S58 & 502,8600 & 1791,267 & 0,036 & 0,718 & tidak \\
\hline S59 & 502,8880 & 1791,094 & 0,039 & 0,718 & tidak \\
\hline S60 & 502,8400 & 1793,057 & 0,013 & 0,718 & tidak \\
\hline S61 & 502,8200 & 1797,535 & $-0,044$ & 0,719 & tidak \\
\hline S62 & 502,8680 & 1793,325 & 0,009 & 0,718 & tidak \\
\hline S63 & 502,7660 & 1775,691 & 0,261 & 0,715 & valid \\
\hline S64 & 503,4060 & 1763,348 & 0,363 & 0,713 & valid \\
\hline S65 & 503,3280 & 1764,702 & 0,341 & 0,713 & valid \\
\hline S66 & 503,0060 & 1765,501 & 0,346 & 0,713 & valid \\
\hline S67 & 503,1860 & 1792,488 & 0,015 & 0,718 & tidak \\
\hline S68 & 502,8700 & 1785,532 & 0,102 & 0,717 & valid \\
\hline S69 & 502,7980 & 1787,717 & 0,077 & 0,717 & tidak \\
\hline S70 & 502,9260 & 1787,459 & 0,071 & 0,717 & tidak \\
\hline JUMLAH & $\mathbf{2 5 3 , 4 5 2 0}$ & $\mathbf{4 4 8 , 7 2 9}$ & $\mathbf{1 , 0 0 0}$ & $\mathbf{0 , 8 4 2}$ & 56 \\
\hline
\end{tabular}

\section{Reliabilitas}

Instrumen yang baik adalah instrumen yang reliabel, artinya instrumen tersebut dapat dipercaya untuk mengukur apa yang akan diukur. Dengan kata lain, instrumen tersebut memberikan hasil konsisten apabila digunakan berkali-kali. Untuk mengetahui hal tersebut, maka dilakukanlah uji reliabilitas dengan menghitung koefisien reliability instrument (cronbach's alpha) uji reliabelitas juga dilakukan untuk program SPSS 24. Hasil uji reliabelitas ditunjukkan oleh tabel berikut.

\section{Tabel 4. Perhitungan Reliabiltas Menggunakan Data SPSS 24 Reliability Statistics}

\begin{tabular}{r|r} 
Cronbach's Alpha & N of Items \\
\hline, 842 & 70 \\
\hline
\end{tabular}

Dari tabel diatas terlihat bahwa nilai reliabilitasnya sebesar 0,842 . karena memiliki nilai reliabilitas lebih besar dari 0,70. Maka kesimpulannya instrumen angket sikap siswa terhadap IPA dinyatakan reliabel. Dari 70 item pernyataan yang dianalisis dengan metode analisis faktor terdapat 56 item valid dan reliabel. Dimana terdapat 14 item yang dihapus karena tidak valid. Dimana 56 item ini tersebar pada 7 indikator sebagai berikut : Implikasi Sosial dari IPA, Normalitas Ilmuan, Sikap Terhadap Penyelidikan dalam IPA, Adopsi dari Sikap Ilmiah, Kesenangan dalam Belajar IPA, Ketertarikan Memperbanyak Waktu Belajar IPA, dan Ketertarikan Berkarir dibidangIPA.

\section{Simpulan dan Saran}

Mata pelajaran IPA merupakan mata pelajaran wajib bagi siswa tingkat Sekolah Menengah Pertama (SMP). Mata pelajaran IPA berkaitan dengan konsep ilmiah. Hasil observasi menunjukkan masih ada asumsi siswa mata pelajaran IPA sulit. Oleh karena itu, penting dilakukan penelitian untuk mengetahui sikap siswa terhadap mata pelajaran IPA.

Berdasarkan hasil penelitian untuk pengembangan instrumen angket sikap yang telah dilakukan di SMP Muaro Jambi diperoleh hasil nilai reliabilitasnya ditunjukan dengan Cronbach Alpha sebesar 0,842. Maka instrumen 
Angket sikap terhadap IPA dinyatakan reliabel dan layak digunakan untuk mengukur sikap siswa terhadap mata pelajaran IPA di tingkat Sekolah Menengah Pertama (SMP).

\section{Ucapan Terima Kasih}

Peneliti mengucapkan terimakasih

kepada program studi pendidikan fisika Universitas Jambi yang telah mendukung dan memberikan fasilitas kepada peneliti untuk menyelesaikan penelitian. Selanjutnya peneliti berterimakasih kepada pihak editor Jurnal Pendidikan Sains (JPS) UNIMUS Bapak Eko Yulianto, M.Pd beserta tim. Pihak sekolah SMP Muaro Jambi yang telah memberikan kesempatan kepada peneliti untuk melakukan penelitian sehingga terlaksana dengan baik serta pihak-pihak lain yang telah berkontribusi dalam penelitian ini.

\section{Daftar Pustaka}

Adams, W.K., et al. (2006). New instrument for measuring student beliefs about physics and learning physics: The Colorado Learning Attitudes about Science Survey. Physical Review Special Topics - Physics Education Research 2,

Blalock, C.,L., et al. 2013. In Pursuit of Validity: A comprehensive review of science attitude instruments 1935-2005. International Journal of Science Education.

Darmawangsa, Rio. (2017). Pengembangan Instrumen Sikap Siswa Sekolah Menengah Atas Terhadap Mata Pelajaran Fisika. Universitas Jambi : Jambi.

Dhamayanti, M., Rachmawati, A. D., Arisanti, N., Setiawati, E. P., Rusmi, V. K., Sekarwana, N. (2018). Validitas dan Reliabilitas Kuesioner Skrining Kekerasan
Terhadap Anak "ICAST-C" versi bahasa Indonesia. Jurnal Keperawatan Padjadjaran, 5(3).

Fraser, B. J. (1981). TOSRA: Test of Sciencerelated Attitudes. Handbook: Australian Council for Educational Research.

Hairida, H. (2017). Pengembangan Instrumen untuk Mengukur Self Efficacy Siswa dalam Pembelajaran Kimia. Edusains, 9(1)

Kamisah Osman., (2006). Sikap Terhadap Sains dalam Kalangan Pelajar Sains di Peringkat Menengah dan Matrikulasi. Http://psasir.upm.edu.

Kasnodihardjo, K. (1993). Langkah-langkah Menyusun Kuesioner. Media Penelitian dan Pengembangan Kesehatan.

Puti, S dan Jumadi. 2015. Pengembangan Modul IPA SMP Berbasis Guided Inquiry Untuk Meningkatkan Keterampilan Proses dan Sikap Ilmiah. Jurnal Pendidikan Matematika dan Sains Tahun III, No.1, Juni 2015. Hal: $1-12$.

Siregar, Syofian. 2015) . Metode Penelitian Kuantitatif dilengkapi dengan perbandingan perhitungan manual \& SPSS. Jakarta:Prenadamedia Group.

Sugiyono, P. DR. (2007)."Metode Penelitian Kuantitatif Kualitatif dan R\&D". CV. Pustaka Setia. Bandung.

Sugiyono. 2016. Metode Penelitian Pendidikan Pendekatan kuantitatif, Kualitatif, dan $R \& D$. Bandung: Alfabeta

Sulistyani, N., \& Retnawati, H. (2015). Pengembangan Perangkat Pembelajaran Bangun Ruang Di Smp Dengan Pendekatan Problem-Based Learning. Jurnal Riset Pendidikan Matematika, 2, 197-210. 